\title{
FRAUD RISK ANALYSIS
}

\section{Artur Piaszczyk}

\section{Key words:}

fraud, risk, analysis, research, action plan, corporate governance, prevention of fraud, ethical principles, control, audit

\begin{abstract}
This article presents and analyzes the issues related to the identification of fraud risk factors and appropriate response to the imminent risk of fraud. The paper presents examples of fraud risk factors in a general way to refer to all aspects of business. Considerations supported the results of research on issues of fraud, which were conducted on a global scale. Also discussed the role of corporate governance in the prevention of fraud.
\end{abstract}

\section{Introduction}

The main objective of this paper is to draw attention to the fact that the risk of fraud in any enterprise is very serious, and therefore worthy of research.

The risk of fraud is inextricably linked with the essence of economic activity, namely the desire for profit - often extraordinary one. Tricksters want to achieve just such an "extraordinary gain", except that they tend to use illegal methods. This distinguishes them from normal business operations.

Now, in the era of information society, fraud sometimes takes a very sophisticated form, and thus is difficult to detect. Sometimes, very primitive fraud are committed, and they remain undetected for a long time. Therefore it is extremely important to be able to identify risk factors conducive to fraud, and also know how to minimize this risk. It is also important to know what action to take when a risk already materialises, or will become a reality.

\section{General comments on fraud}

There is no single, universally accepted definition of fraud or corruption. One of the definitions, which used by the Association of Certified Fraud Examiners (ACFE) the United States understands that the misuse of position is: "use of position to enrich themselves by deliberate abuse or misuse of resources or assets of the employing company" ${ }^{1}$. This definition also uses Joseph Wells, founder and president of ACFE, already in his famous publication on economic fraud Fri "Corporate Fraud Handbook: Prevention and Detection" 2

The first report of the 1996 ACFE notes that fraud in the companies has the following features:

- is made in secret,

- affects the employee's duties to the company,

- aim is to obtain direct or indirect financial benefits,

- depletes your assets.

\footnotetext{
${ }^{1}$ Association of Certified Fraud Examiners (ACFE), Report to the Nation on Occupational Fraud and Abuse, 1996.

2 JT Wells, Corporate Fraud Handbook: Prevention and Detection, Polish edition, LexisNexis, Warszawa 2006, p.1.
} 
Irregularities may be committed by individual employees, a group of employees acting in collusion, as well as by employees acting in collusion with persons outside the organization. The most dangerous is, of course, abuse committed by a larger number of employees working together. Such abuse can remain long undetected and expose the company to significant losses.

ACFE distinguishes three main categories of abuse in the companies:

- misappropriation of assets, which includes a broad theft and misuse of assets of the organization. The most common cases are: theft of cash, stock theft, presenting inflated or fictitious accounts;

- corruption, where the employee uses his influence on decision-making in order to achieve financial gain for himself or a third party. The most common cases are: accepting bribes and engaging in conflict of interest;

- falsification of accounts, which means any intentional distortion of financial and management information. The most common events were overstating revenues and out of liabilities or expenses ${ }^{3}$.

\section{Results of research on issues of fraud}

The study shows ${ }^{4}$ that employees commit fraud if they believe that by unfair conduct they may gain more than lose. When an employee is allowed abuse one can observe the existence of three factors:

- opportunity - cheating is possible only if the employee has the option of filing, as a rule, this option provides for a lack of adequate internal control mechanisms, for example, improper segregation of duties;

- motive - also known as pressure, abuse is not made without reason, the employee must have a impulse, which will encourage him to malfunction - this subject could be: strong pressure on the results of financial or personal problems;

- justification - also known as the explanation, a dishonest employee must justify to himself why dishonesty is not something reprehensible, for example, distorts the financial statements in order to save jobs for many other people, or overstates expenses of the service, because the employer does not appreciate it.

Knowledge and correct understanding of the above scheme is important in preventing abuse. The primary responsibility for prevention and combating fraud in the organization rests with the leadership of the unit.

Studies show ${ }^{5}$ that economic abuse is a serious problem in the business. As many as $20 \%$ of companies in the world were therefore a very serious crisis. In Poland, the crisis associated with fraud, was nearly $40 \%$ of the surveyed companies. Scams are too expensive. They cost the global economy the loss of up to $5 \%$ of revenues (conservative estimate) ${ }^{6}$, and only $20 \%$ of the loss is recovered from the perpetrators of abuse. The chart below shows, the most common scams for the whole world economy .

\footnotetext{
${ }^{3}$ Applies to the U.S. economy. In Europe, especially Central and Eastern Europe, dominated by the opposite action, namely the diminishing income or overstating expenses in order to deduct the tax base; see: A. Piaszczyk, Audyt śledczy, Europejskie Centrum Ekonomiczne Prestiż, Lublin 2009, p. 13.

${ }^{4}$ DR Cressey, Other People's Money, Montclair, NJ: Patterson Smith, 1973, p. 3.

${ }^{5}$ IX World survey of economic abuse. Fraud risk in emerging markets, Ernst \& Young, 2006.

${ }^{6}$ Association of Certified Fraud Examiners (ACFE), Report to the Nation on Occupational Fraud and Abuse, 1996.
} 
Figure 1 The most common scams in reality

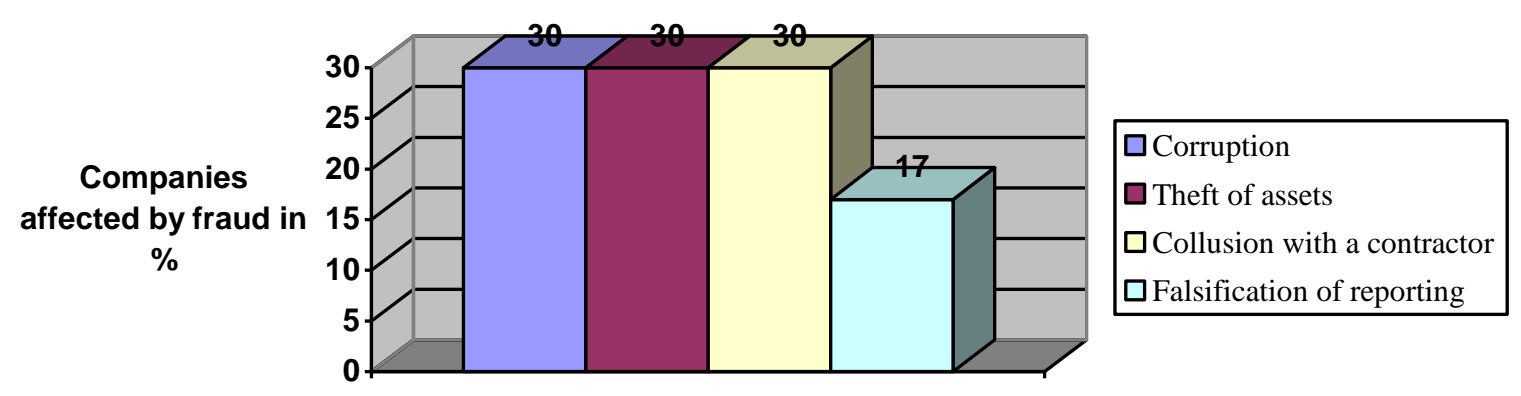

Source: World IX fraud investigation. Fraud risk in emerging markets, Ernst \& Young, 2006.

As many as $48 \%$ of surveyed companies operating in emerging markets, including Poland, indicate corruption, bribery, and 20\% - employees collusion with third parties such as fellow contractors or suppliers as the greatest threat. However in the world, as the most serious risk, indicated abuse associated with the financial statements of companies. "Creative accounting" for many, even the largest companies in the west, turned out to be a cover, which was to hide losses, and often, fraud management.

\section{Causes of fraud}

Causes of fraud are different, but in a large proportion of cases, the responsibility for it falls on the management of companies that ignores potential risks. Such conclusions can be drawn based on studies conducted in thirteen European countries, including Poland. The studies took part in them $^{7}$ involving 1300 employees and 600 multinational managers ${ }^{8}$.

Most errors committed by the management, are the result of the following reasons:

1. Over-confidence - our employees do not commit fraud. Entrepreneurs who invest in staff, promoted them to higher positions and reward, cannot avoid thinking that these would be ungrateful. The longer someone works in a company, the employer has more confidence in him. The study shows, however, that the typical fraudster does not need to be newly employed person. On the contrary, it is usually associated with an employer working on average from 3 to 5 years. With the promotion, increased responsibility and independence of the employee comes.

2. No cases of fraud in the past. Meanwhile, this phenomenon occurs in all countries and industries, in companies that are better or worse managed, public and private. The risk increases particularly during the reorganization of the business, marketing new products or the company's expansion into new markets. Historical data, regarding the absence of fraud in the past, they have no leverage on the situation of the company at the time.

3. Ignoring warning. The basic mistake is to ignore the early signs of the problem. Nothing emboldens impunity to crooks like, so you must react to the slightest signs of dishonesty.

\footnotetext{
${ }^{7}$ Abuse from the perspective of a serial worker, Ernst \& Young, 2007.

${ }^{8}$ Do not be surprised, or how to effectively fight fraud in the company, Harvard Bussiness Review Poland Brief, supplement to number 3 / 2007 HBRP.
} 
This may deter potential fraudsters. Excellent illustration of this problem is the case of Bernard Madoff's pyramid scheme. Since, at least, 2001, there were signs that Madoff's business is speculative and is, in fact, fraudulent. However, these warnings have been systematically ignored by more than 7 years, until December 2008, when Madoff revealed his scam alone?

4. Conviction that management controls the key areas and relies on intuition rather than on analytical and comprehensive approach to the risk of fraud. As a result, an intuitive approach, management draws its attention to areas in which it is easiest to detect fraud, and not to areas where risk is the greatest. 63\% of companies focus on cases of theft of assets, and $50 \%$ of companies were involved in the crime of using a computer. Only $21 \%$ of surveyed companies were interested in the risk of falsification of reporting.

5. Conviction that even if fraud occurs, control mechanisms will certainly detect them. If no mechanisms are detected, management confirms his belief (often erroneous) that the fraud in their companies does not occur. This situation means that management does not see the need to hire experts in fraud detection, or trained staff in this respect $(38 \%$ of surveyed companies). As experience shows, however, that most of the control mechanisms used to detect errors and inefficiencies in processes and their prevention, and not against an informed and deliberate fraud. In addition, many people, including senior management, by virtue of their positions can easily circumvent controls and commit fraud. In situations where a determined worker, devoid of ethical brakes works under strong pressure to circumvent the system of internal control can only be a matter of time. Controls are a very important element of protection against fraud, but insufficient.

6. Conviction that losses will not be large. Entrepreneurs do not appreciate the impact that abuse can have on their business activities. Many of them believe that the consequences of abuse are not too important. And if it already comes to fraud, it is easy to recover lost property. Some people believe that insurance will cover the losses. In fact, only $20 \%$ of the loss is recovered from the perpetrators of fraud, and insurance covers $19 \%$ of losses, which means that $61 \%$ of the losses will remain unrecovered. Additionally, you should expect a loss of reputation, which can cause a decline in share value, a loss of customer confidence, and other hard to estimate losses. According to the data ${ }^{10}$, the average loss resulting from fraud is about 500 thousand the Polish Zloty (PLN) (approximately \$ 170 thousand.), and the median duration of fraud is $\mathbf{1 8}$ months.

\section{The action plan in case of detection of fraud}

It is impossible to eliminate fraud and abuse. Nevertheless, it is important to at least reduce their number and minimize their negative effects. To accomplish this, the company needs a plan of action in case of detection of fraud.

Basic conditions to protect oneself from fraud or minimize their effects, are as follows:

1. The establishment of formal rules in the company, which define precisely what is a scam. Examples of such activities are the introduction of corporate governance rules, in many companies, called the Code of Ethics and Good Practices. In Poland, these documents are mainly listed companies. Employees should know them and they should be obliged (in

\footnotetext{
${ }^{9}$ See. T. Jóźwik, Lied to almost everyone, Forbes 2009, No. 2.

${ }^{10}$ Association of Certified Fraud Examiners (ACFE), Report to the Nation on Occupational Fraud and Abuse, 2006.
} 
writing), to follow them. Polish workers admit that almost the half of them do not have in his company any anti-fraud procedures, and if any, is at $60 \%$ have not been translated into Polish or transferred employees ${ }^{11}$.

2. Awareness of employees. Employees should know how to recognize even the basic symptoms of fraud such as the lack of long-term leave, notorious staying after hours, or continuous cooperation of the same people.

3. The establishment of information channels. Employees should be able to inform anonymously their superiors (as well as top management) about potential scams. These can include special phone numbers and email addresses, but always they must be guaranteed anonymity.

4. Implementation of internal audit and the institutional internal control. Specialized controllers have a professional preparation for the detection of the offense.

5. Creating an action plan that clearly specifies the parties responsible for the actions in a crisis situation, defines the necessary tasks, their sequence, manner and mode of preservation of evidence and how to communicate with management and possibly the public.

All the issues are important, but crucial role is played by an action plan. Such a plan can be likened to a crisis management plan, and therefore an emergency situation, because any fraud - to a lesser or greater extent - the company calls the crisis.

An effective plan should include at least the following elements:

1. Preliminary verification of information about fraud - the type of filter. Further investigation depends on the results of the verification.

2. Description of the situation, which will usher in the action, and prioritize. Please describe situations that require the commencement of the action (for example, theft, falsifying records, etc.) as well as establish their hierarchy. For example, the suspected falsification of accounts requires the participation of members of the leadership in the investigation, the investigation into the theft, to a certain amount, is conducted by the internal audit function.

3. The division of responsibilities and powers and decision-making mode. Please specify who in a given case will make decisions, who will join the investigation team and what responsibilities team members will have, such as: the preservation of evidence, interviews with witnesses and suspects, reporting to management. At the time of the emergency, everyone should know exactly what to do along with the power to eliminate improvisation.

4. Securing the continuity of the company - conducted investigation should be so organized, so as not to interfere with normal activities.

5. Securing evidence:

- materials should be original,

- records of the circulation of material, from whom it comes, who, when and to whom it was given and those who had access to it,

- non-interference in the original form of the material,

- store in a place with limited access,

- prohibition of violations of personal data and privacy of correspondence.

${ }^{11}$ Abuse from the perspective of a serial worker, Ernst \& Young, 2007. 
6. Proceedings of the suspect, preventing him from destroying evidence.

7. Conducting interviews with witnesses and suspects, you should:

- determine the order of interviews, starting with the witnesses, and ending with the suspect,

- gather information about interlocutors,

- determine if they are in the company, to conduct discussions about the preparation of professional people

- ensure that the conversation is voluntary,

- ensure the participation of at least two people from the employer,

- draw up a protocol acceptable explanation, possibly signed by the person granting clarification,

- hold talks separately with each of the witnesses and suspects, or perform a confrontation with several people.

8. Communication with the environment (people, public opinion). It is necessary to determine who and what environment will be informed of the progress of the investigation, assuming the presumption of innocence of suspects. No official information raises, most often, a wave of rumors and speculation.

These actions are the actions of the system, and refer to the entire company and all employees. But the most important role is played by the company management, which should continuously analyze the risk of fraud, and above all implement controls and monitor their performance.

The basic elements of control mechanisms could include the following:

- written procedures (Book of Procedures) ${ }^{12}$,

- internal control and internal audit,

- a detailed verification of employees applying for a key or critical positions (a company needs to create such a list of positions and create an audit trail in force during recruitment),

- staff turnover,

- segregation of duties and authorization (for example, payments above certain amounts),

- detailed records,

- inventories,

- negotiated independent accounts,

- report on abuse channels, ie. hot lines, telephones to ensure anonymity, e-mail addresses, etc.,

- verification of contractors, for example by the National Court Register (you know who sits on the board and who has power of attorney to represent),

- security guards,

- industrial cameras.

\section{The role of corporate governance in the prevention of fraud}

In the fight against fraud what is also important is the role of proper ethical environment within the company and giving an appropriate example of the "top". It is difficult to overestimate the

\footnotetext{
${ }^{12}$ To establish the Book of Procedures shall be obliged entities benefiting from EU funds. Other company, but do not have such responsibilities, should have such a document, due to their own advantage.
} 
role of the audit committee, acting in the structure of the supervisory board, the corporate governance. Currently in Poland, the creation of audit committees within the supervisory board is mandatory. This follows both from the EU rules ${ }^{13}$ and the Polish law. Here are the key tasks which an audit committee in dealing with abuse faces.

\subsection{Promotion of ethical principles and oversight of their compliance}

One of the basic steps in building a proper ethical environment that fosters the prevention of fraud, is to create a climate of openness and individual responsibility. The audit committee should demonstrate readiness to receive information and to encourage internal and external auditors to report any concerns about abuse.

In addition, the audit committee should make sure that your organization exists and has been properly communicated to the formal rules of ethics and appropriate behavior undesirable. The audit committee should receive reports on identified breaches of these principles, regardless of their significance. It should also be positively distinguished by those managers who disclose irregularities and take action to clarify them.

\subsection{Ensuring the completeness of the data and access to a wider group of employees}

Senior management in many cases, filters information, which arrives to the audit committee. By means of the audit committee access is obtained to employees and lower or middle level managers, what enables them to report the problems identified; this will allow the audit committee to assess the quality of management and to obtain complete first hand information. In addition, an effective tool for studying the properties of the organizational climate can be regular surveys among key employees on awareness of abuse and conduct leadership in this area.

\subsection{Providing appropriate processes and controls}

Control mechanisms are an important part of combating fraud. In research ${ }^{14}$ that are considered the most effective weapon. The audit committee should collect information about the specific abuse occurring in the industry to ensure that appropriate control mechanisms, limit the risk. The audit committee should remain in constant contact with internal and external auditors regarding the adequacy and effectiveness of existing controls and the possible need to strengthen them. Audit plan should include the areas of increased risk of fraud. It should however be noted that the control mechanisms alone are not sufficient to protect against fraud.

\subsection{Appropriate response in cases of abuse}

Appropriate decisions taken by management in cases of abuse are a very important part of creating the right organizational culture. Employees must be aware that the unit will prosecute fraudsters and claim compensation for damage caused by them. The audit committee should request the removal of people from the organisation who commit fraud and to inform law enforcement authorities and attempting to recover losses.

\subsection{Ensure proper procedures in cases of detected fraud}

When abuse is discovered, or there is a sufficient number of signals to assume that it was committed, the next steps should be carried out very quickly.

\footnotetext{
${ }^{13}$ Directive 2006/43/EC of the European Parliament and the Council of 17 May 2006 on statutory audits of annual accounts and consolidated accounts.

${ }^{14}$ IX World survey of economic abuse. Fraud risk in emerging markets, Ernst \& Young, 2006.
} 
Depending on the type and extent of abuse it is a different way of explaining the matter. In cases of fraud perpetrated on the lower level of organization of the investigation may be conducted by internal audit, in accordance with the legitimacy of the organization and scope of assigned authority. The audit committee should exercise supervision over such investigations. When there is suspicion of having committed a more serious and complex fraud or associated with the senior management, the audit committee should assume responsibility for the investigation or require notification of law enforcement.

The aim of this investigation is to answer the following questions:

1. Who is in the circle suspected of fraud?

2. How the fraud was committed?

3. Why was there a fraud?

4. What is the scope and value of fraud?

5. Does fraud have an impact on the financial statements?

\subsection{The cooperation committee with internal and external auditor}

In order to prevent fraud properly, the audit committee must properly understand the responsibilities of internal audit and external audit is to detect fraud, in order to be able to coordinate their work.

In accordance with International Standards on Auditing, the role of an auditor is not to search for possible fraud. Therefore, please note that due to the nature of the auditor's tests, some significant abuse may not be detected. The role of the audit committee may include the issuing of recommendations from the experts to conclude an agreement which commits him to design a study with a particular reference to the possibility of abuse. It is worth noting because the risk of undetected material fraud is much higher than the risk of undetected material misstatement due to a mistake, because abuse is usually associated with attempts to suppress them. The audit committee should obtain information from the auditor about how the expert takes into account the risk of fraud during the test.

In the event of disclosures of abuse or suspicions of abuse, even if their impact on testing the reliability and accuracy of financial statements is not significant, the auditor should be required to notify the supervisor promptly in writing of the person or the cell in which fraud, errors, or an infringement took place. If members of the management committed the abuse the audit committee should be informed about that.

An internal audit plays a very important role in preventing abuse. It should take action to reduce the number of cases of fraud and limiting the consequences. Internal auditors are responsible for assisting management in preventing abuse by reviewing and evaluating the adequacy and effectiveness of internal control systems in a manner appropriate to the potential risks in different areas of the organization. In case of weakness of this system, the internal auditor's responsibility is to present recommendations for the introduction or extension of cost-effective controls to prevent abuse.

According to the standards, the internal auditor should have sufficient knowledge to recognize the signs of offense. Also, audit procedures, even if they are done with care, do not guarantee that fraud will be detected. In a situation where the internal auditor suspects that irregularities have 
taken place, is obliged to notify the head of the unit. At this point he should consider whether he should inform the other authorities, such as a supervisory board or audit committee. The internal auditor may recommend the carrying out specific activities, depending on the situation. Internal audit is the responsibility of the monitoring activities undertaken by the notification of irregularities.

\section{Fraud risk management during the recent global crisis}

In 2011, Ernst \& Young conducted a further study entitled "European Fraud Survey 2011"15. The study was conducted in the form of a survey among 2300 companies in 25 European countries.

The conclusions show that there is a link between the crisis and the increase in unethical behavior. We can generally say that in tough times there is no moral economy. For example, in Germany, almost 60 percent of all respondents believe that in difficult times, leadership is to achieve its goals at any cost, and therefore does not attach much importance to morality. Among the leaders even 78 percent of respondents are of the opinion.

In European countries, during the crisis, almost 1 in 5 company employees, regardless of grade, considers it acceptable to pay bribes to win or retain business. Ready for giving cash gifts is especially common in Greece and Russia. And the most honest companies are in France and Norway.

Survey has indicated that companies struggle to ensure that what they have in place on paper is actually reflected in the underlying behavior of their staff. Survey indicates also that:

Management is failing to set a strong tone at the top of many organizations and, in many cases, is prepared to do whatever it takes to succeed

A persistently high level of employees are willing to behave unethically

Companies are not doing enough to implement and communicate anti-fraud and anti-corruption measures $^{16}$.

\section{Conclusion}

Management of companies often underestimates the problem of fraud, believing that their companies are not concerned. Fallacy of this assumption has been proven through numerous studies conducted around the world. No operator can feel free from abuse committed by employees, what is more, it appears that the fraud committed by experienced staff, with several years' experience in the company.

Eliminating fraud is not possible, but can be effectively reduced. JT Wells writes, "It turns out that (...) the conviction of the inevitability of detection is inversely proportional to the theft, ie, the stronger is the conviction that the theft is discovered, the less likely that the employee will behave inappropriately"17. It is therefore important that the management company has implemented a program whose goal is to present a permanent analysis of the risk of fraud, and prevent and detect any fraud. Employees should be convinced that there is no tolerance for this

\footnotetext{
${ }^{15}$ Ernst \& Young, European fraud survey 2011 - Recovery, regulation and integrity, 2011.

${ }^{16}$ Ibid., p. 23.

17 JT Wells, Corporate Fraud Handbook: Prevention and Detection, Polish edition, LexisNexis, Warszawa 2006, p.23.
} 
type of action, and detected fraud will be reported to law enforcement authorities. Only a hard stance against fraud may in practice reduce these negative behaviors and be a warning to other potential fraudsters.

\section{Literature:}

[1] Association of Certified Fraud Examiners (ACFE), Report to the Nation on Occupational Fraud and Abuse, 1996 and 2006.

[2] Cressey DR, Other People's Money. Montclair, NJ: Patterson Smith, 1973.

[3] Ernst \& Young, IX World survey of economic abuse. Fraud risk in emerging markets, 2006.

[4] Ernst \& Young, Abuse from the perspective of a serial worker, 2007.

[5] Ernst \& Young, European fraud survey 2011 - Recovery, regulation and integrity, 2011.

[6] Harvard Bussiness Review Poland Brief, Do not be surprised, or how to effectively fight fraud in the company, supplement to number 3 / 2007 HBRP.

[7] Jóźwik T., Lied to almost everyone, Forbes 2009, No. 2.

[8] Piaszczyk A, Audyt śledczy. Lublin: Europejskie Centrum Ekonomiczne Prestiż, 2009, 109 p. ISBN 978-83-928588-1-2.

[9] Wells JT, Corporate Fraud Handbook: Prevention and Detection. Polish edition, Warszawa: LexisNexis, 2006, 440 p. ISBN-10: 83-923433-1-X, ISBN-13: 978-83-923433-1-8.

Classification JEL: G32, M42

\section{Artur Piaszczyk, Ph.D.}

Internal auditor at the Jagiellonian University in Krakow, Poland

Czapski street 4, 31-110 Krakow, Poland

artur.piaszczyk@uj.edu.pl

Lecturer at the Chair of Banking and Finance

School of Finance and Law in Bielsko-Biala, Poland

Tanski street 5, 43-382 Bielsko-Biala, Poland

piaartur@interia.pl 